DOI: https://doi.org/10.32839/2304-5809/2021-11-99-20

УДК 004.91

Мамонтов В.В., Березінський Г.В.

Національний технічний університет України

«Київський політехнічний інститут імені Ігоря Сікорського»

\title{
АНАЛІЗ НАУКОМЕТРИЧНИХ ДАНИХ НАУКОВЦІВ НА ОСНОВІ ГРАФУ СПIВАВТОРСТВА
}

\begin{abstract}
Анотація. Стаття присвячена дослідженню методів аналізу даних наукової діяльності груп науковців, об’еднаних у наукові підрозділи, використовуючи графову структуру даних. Також ставиться задача візуалізації отриманих даних з метою спрощення прийняття управлінських рішень адміністрацією закладів науки та освіти. Робота проведена на основні інформації про науковців, що діють у рамках закладу вищої освіти НТУУ «КПI ім. Ігоря Сікорського» та даних, взятих з відкритого джерела - загальнодоступного індексатора Google Scholar. У статті описаний збір даних, методологія побудови графру взаємодії науковців, наведено приклади використання графру для аналізу наукометричної діяльності окремих науковців, та впливу окремих груп науковців на показники загальної групи, що досліджується. Для аналізу використано методи типізації, обчислено показники центральності та вирішена задача про кліку графру. На основі візуалізації даних та виділення кліки зроблено висновки щодо можливості використання результатів аналізу для прийняття управлінських рішень. Дані підходи можуть бути використані для аналогічної аналізу та візуалізації інших груп.
\end{abstract}

Ключові слова: наукометрія, Google Scholar, графр, графрічне представлення, візуалізація, типізація, показник центральності, ступінь посередництва, неорієнтований граф, зважений граф h-індекс, індекс Хірша.

Mamontov Vladyslav, Berezinskyi Hennadii National Technical University of Ukraine «Igor Sikorsky Kyiv Polytechnic Institute»

\section{ADVANCED METHODS OF ANALYSIS OF SCIENTIFIC METRIC DATA}

Summary. The purpose of this work is to develop approaches that help in making management decisions by the administration of scientific and educational institutions by studying methods for analyzing data from scientific activities of groups of scientists, united in scientific units, using a graph data structure. Visualization of a graph data structure will facilitate empirical perception and simplify the process of making decisions. The work is based on basic information about scientists working within the National Technical University of Ukraine "Igor Sikorsky Kyiv Polytechnic Institute" and data taken from an open source - the Google Scholar indexer. The article describes data collection, method for constructing a graph of interaction between scientists, gives examples of using the graph to analyze the scientometric activities of individual scientists, and the influence of individual groups of scientists on the indicators of the studied general group. Examples of conclusions that can be drawn based on visualized data are given. For the analysis, typification methods were used, centrality indicators were calculated, and the Clique problem on a graph was solved. Methods allow to define the most perspective groups of scientists, to reveal influence of the scientist or groups of scientists on the general picture of scientific activity in the set scientific division. The result of this work is a demonstration of a practical way to use information about the activities of scientists to study the effectiveness and identify the most promising areas. It can be used for similar visualization and analysis of any group of scientists. The article presents an urgent problem, provides an analysis of all solutions, proposes a method of solving previously undisclosed issues. The result of this work is a demonstration of a practical way to use information about the activities of scientists to study the effectiveness and identify the most promising areas. The article allows to conclude the high potential of using a graphical structure for working with scientometric data, since the method provides ample opportunities for their processing, while leaving the possibility of simple visualization.

Keywords: scientifics, google scholar, graph, graphic representation, visualization, typification, centrality indicator, betweenness centrality, h-index, Hirsch index, Hirsch number, non-oriented graph.

Постановка проблеми. Оцінці наукової діяльності дослідників присвячено безліч публікащій і розроблений ряд підходів $[1 ; 2]$. Найбільш широко вони застосовуються для ощінки результативності праці науково-педагогічних співробітників університетів, наукових інститутів і приватних компаній. Аналіз отриманих оцінок, та в цілому наукової діяльності, дозволяе визначити найбільш перспективні галузі, що зараз розвиваються. Що більш важливо - визначити круг конкретних науковщів, що вносять найбільший вклад у розвиток наукової області, в якій працюють. Результати дозволять звернути увагу та направити фрінансування на найбільш перспективні проекти.

Кожен 3 індексаторів має свої критерії відбору наукових публікацій та включення їх до бази даних, а також свої конкретні розрахунки наукометричних показників. Якщо зараз правила відбору журналів в індексах Web of Science i Scopus найжорсткіші, то система Google Scholar, навпаки, є найпоширенішою системою, що збирає всі наукові публікації в Інтернеті, включаючи репозиторії відкритого доступу, особисті сторінки вчених та університетські електронні бібліотеки. Лише після їх загального аналізу можна дати правильну оцінку діяльності науковця. Тому проблема фрормування консолідованих рейтингів та комплексного аналізу залишається актуальною. Такий аналіз та порівняння науковців, при його використанні, буде мати суттевий вплив на вибір напрямків фрінансування наукової діяльності та прийнятті інших управлінських рішень. 
Наразі відсутні запропоновані рішення представлення великого масиву наукометричних даних науковців та їх комплексного аналізу.

Аналіз останніх досліджень і публікацій. Раніше автори статті вже розглядали вимоги до системи показників наукової діяльності наукових організацій, а також описували основні фрункціональні можливості їі першої версії [3; 4]. Роботи спрямовані на вирішення проблем відсутності єдиної бази наукометричних показників науковців в рамках одного наукового підрозділу, що не дає можливості провести аналіз в повній мірі. Напрямками аналізу були визначення ефрективності роботи окремих науковців, або груп.

Робота [5] присвячена дослідженню активності видавничої діяльності профресорсько-викладацького складу (ППС) ЗВО. Представлені результати можуть бути корисні адміністрації ЗВО для оцінки поточного стану наукової діяльності. Дана робота не має диференціації аналізу в залежності від ресурсу, не враховує деякі базові показники (наприклад, кількість посилань), не бере до уваги дані з pecypcy Google Scholar. В Україні популярність Google Scholar є значно вищою.

Робота [6] підіймає питання можливості побудови моделей, що автоматично визначають, які особливості є важливими. Це б дало змогу обходити етап функціональної інженерії при аналізі даних. У статті описано спосіб застосування таких методів у наукометрії. Стаття є теоретичною. Автор не пропонуе конкретного методу аналізу та не наводить результати роботи, яка була б проведена 3 використанням методів машинного навчання.

Загальною особливістю усіх розглянутих робіт з даної тематики є відсутність опису методу отримання даних (існують складнощі з відтворенням результатів).

Виділення невирішених раніше частин загальної проблеми. Дослідження $є$ продовженням робіт [3; 4], що полягають у зборі та попередньому аналізі наукометричних даних науковців, які працюють на базі закладу вищої освіти (ЗВО) Національного технічного університету України «Київський Політехнічний Інститут імені Ігоря Сікорського». У зазначених роботах було зібрано та проаналізовано дані на базі університету, де проблема фрінансування $є$ особливо актуальною.

Можна виділити наступні недоліки цих робіт:

- візуалізащія даних не спрямована на відображення узагальнених результатів;

- аналіз даних має вузький спектр;

- аналіз проводиться у рамках заздалегідь визначених підрозділів. У даній роботі підрозділи для аналізу будуть формуватися, у тому числі, на основі отриманих показників (наприклад, визначення кліки графру).

У статті описано нові особливості системи, їі сучасний стан та потенційні результати їі використання у вищих навчальних закладах.

Формування цілей статті. Метою даної роботи $є$ розробка підходів для допомоги в прийнятті управлінських рішень адміністрацією закладів науки та освіти. Для цього використовуються методи аналізу наукометричних показників групи науковців, що дозволяють визначати найбільш перспективні підгрупи, виявляти вплив вченого, або групи вчених, на загальну картину наукової діяльності у заданому науковому підрозділі. Підрозділом є група вчених, що об’еднана за певним обраним критерієм, яким можуть бути спільна спеціальність, фракультет, або заклад науки чи освіти.

Для представлення даних використано технології візуалізації. Їх призначенням у роботі $\epsilon$ спрощення прийняття управлінських рішень на основі великих масивів даних, що необхідно представити у емпіричній формі.

Результати роботи показано на прикладі вчених, що ведуть наукову та викладацьку діяльність у межах НТУУ «КПІ ім. Ігоря Сікорського».

Виклад основного матеріалу дослідження. Для аналізу наукометричних даних, а також для їх візуалізащії з метою прийняття управлінських рішень, було обрано графову структуру даних. Побудова графу відбуваеться на основі відношень науковців у контексті наявності та кількості спільних публікацій. Це дозволило візуалізувати зв'язки між науковцями, вклад кожного 3 них, а також сфрормувати уявлення про вплив підрозділів на загальні показники.

На графрі відображені вузли (науковці), ребра, що їх з'єднують за наявністю спільних наукових робіт, та вага ребер (кількість спільних наукових робіт). Ребра графу складають об'єднані публікації, що індексуються у профрілях науковців Google Scholar. Петлі на графрі дозволяють відобразити загальну кількість наукових робіт автора. На виході роботи програми отримано неорієнтований зважений граф, у якому вага кожного ребра рівна кількості спільно написаних робіт пари вчених, що відповідають з'єднаним вершинам.

Дані для аналізу отримані з наукометричних баз Google Scholar та Scopus за допомогою синтаксичного аналізатору, що збирае інформацію у єдину базу. Система проведення аналізу може використовувати дані 3 обох ресурсів. У даній статті розглядаються наукометричні дані, що були взяті з бази Google Scholar, оскільки ця база $€$ відкритою, та містить індормацію про більшу кількість науковців та їх робіт.

Для аналізу використано дані з бази, актуальні станом на травень 2020 року. Це дає змогу бути впевненими, що всі використані статі станом натепер пройшли індексацію.

База даних містить записи про 2694 науковця та 63456 статі з pecypcy Google Scholar. Усього маємо 6664 пари науковців 3 різною кількістю наукових робіт. Це число показуе спільну наукову активність. Міститься також інформація про науковців, що вже не займають зазначені посади. Це пов'язано з тим, що переважна більшість не вносить відповідних змін до профрілю після виходу у відставку. Такі науковці утворюють похибки у результатах аналізу.

Для аналізу у контексті визначення найбільш продуктивних груп науковців та дослідження комунікації між підрозділами, є малоінформативними науковщі, що мають низьку кількість публікацій, або не мають спільних робіт з іншими членами наукових підрозділів. Для побудови інформативної графової структури необхідно провести очистку даних, що включила у себе:

- видалення вершин, що не мають зв'язків 3 іншими (науковщі, чиї статі були написані без співавторів у межах досліджуваної наукової бази); 
- видалення найменш впливових вершин науковців, що мають низьке число робіт та одночасно мають мінімальну кількість співавторів у межах досліджуваного закладу науки. Це дозволило виключити 3 аналізу наукових співробітників низьких рангів (магістрів та аспірантів), що мають декілька публікацій, написаних виключно 3 метою захисту наукового звання. Таким чином було виокремлено реальних співробітників закладу науки.

У результаті описаних операцій досліджувані дані скоротилися на 1175 вершин, для подальшого аналізу залишено 1519 вузлів графу.

Наступним кроком було виконано типізацію даних для можливості отримання візуальних характеристик впливовості того чи іншого типу. Було зроблено типізацію для двох характеристик об'єкта графра - колір та розмір вершини. Колір вузла використовувався для позначення науковців, що діють в рамках одного науково навчального інституту або факультету. За параметр розміру вузлів відповідає ступінь посередництва вузла графу. Проведена типізація дала змогу побачити, які саме 3 факультетів, та які конкретні науковці мають найбільший вплив на поточні загальні наукометричні показники.

Важливим показником при емпіричному аналізі графу $є$ показник ступеня посередництва вузлів. Він визначається як сума частки всіх пар найкоротших шляхів, які проходять через обраний вузол. Визначення також формують наступним чином: ступінь посередництва кожної вершини дорівнюе числу найкоротших шляхів через вершину [7]. Даний показник являється мірою центральності вершин графру.

Показник центральності вершини визначає найважливіші вершини графу - вони є найбільш впливові у соціальних мережах, соціальних структура, комп'ютерних мережах [8]. Важлива властивість вузлів, що мають високий показник центральності - вилучення цих вершин потенційно призведе до поділу графра на два незв'язних графра та/або значному збільшенню багатьох значень найкоротших шляхів.

Маємо змогу зробити наступний висновок - зі збільшення показника центральності зростає значимість вузла (автора) у загальній тенденції написання наукових робіт та співробітництві науковців.

На рисунку 1 зображено виділений фррагмент побудованого графру на основі даних про всіх науковців 3ВО. Демонструеться наочна різниця між вузлами 3 різним показником центральності, області скупчення вузлів, кількісна характеристика взаємодії науковців. Фрагмент частково відображається складність вирішуваної задачі. Даний рисунок є демонстраційним, та не містить особистих даних науковців.

Використовуючи побудований графр, чи аналогічні йому графи за заданими підрозділами, можна знаходити інформацію про:

- кооперації між членами різних підрозділів;

- порівнювати ступінь взаємодії науковців у межах одного підрозділу;

- визначати підрозділи з найбільш впливовими науковцями;

- безпосередньо порівнювати необхідну кількість підрозділів між собою та ін.

Визначаючи скупчення груп науковців одного підрозділу у тій чи іншій частині графу, можна збирати свідчення про співробітництво науковців 3 колегами у межах одного підрозділу. Визначаючи переважні кольори сусідніх вершин, можна засвідчити ступінь кооперації між різними підрозділами.

На виділеній області на рисунку 1 можна бачити перевагу вузлів жовтого кольору. Це свідчить про тісну кооперацію науковців 3 фракультету IOT з іншими науковцями у межах свого

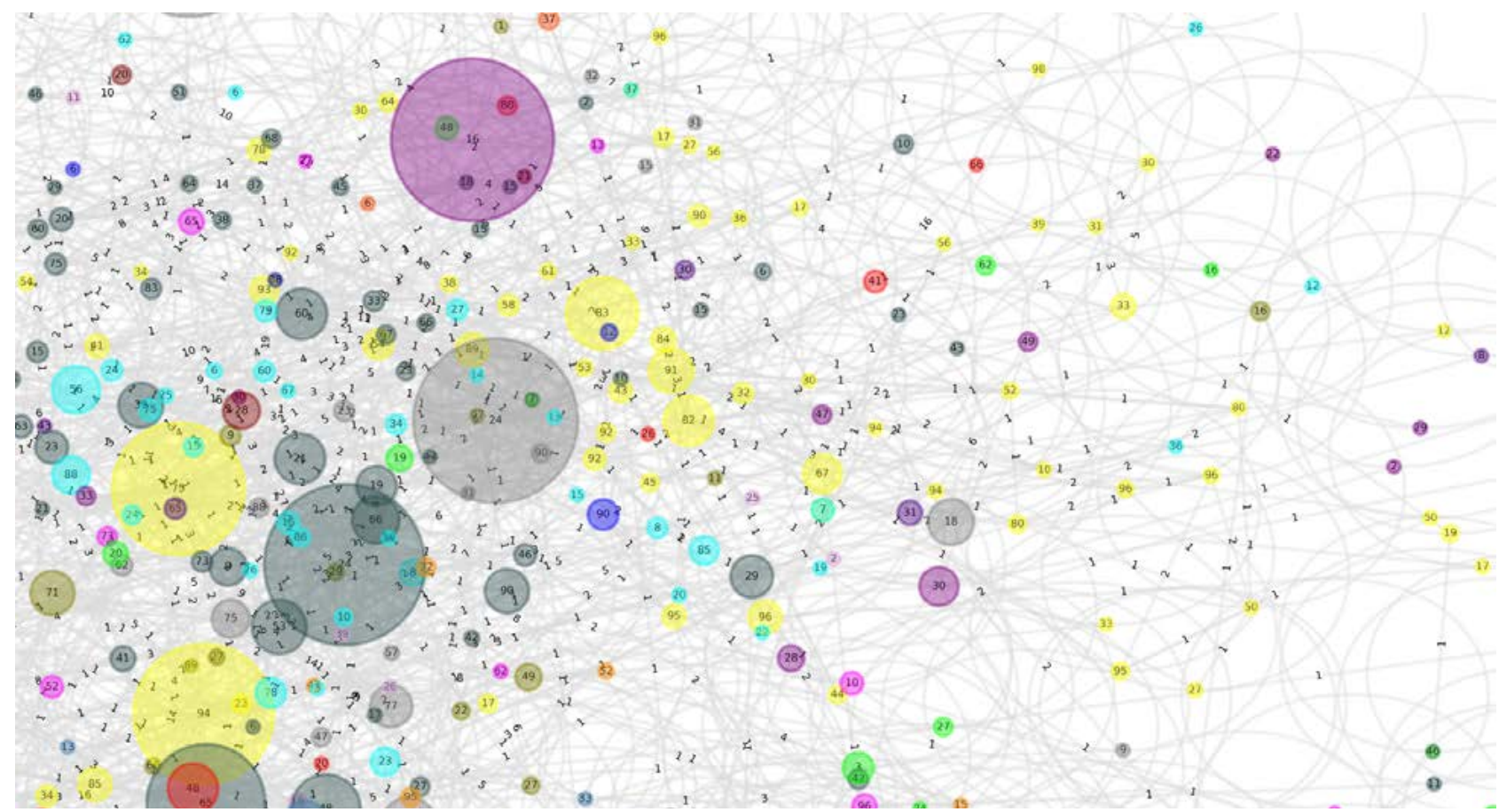

Рис. 1. Приклад фрагменту побудованого графу 
фракультету. Присутні щонайменше 3 вузли з великим показником центральності. В результаті можна зробити висновок про вдало підібраний склад наукового підрозділу та високу ефективність його членів. Поряд з вузлами жовтого кольору присутня велика кількість вузлів ціанового кольору, що з-поміж іншого, свідчить про тісну кооперацію ФIОТ з науковцями IAT.

Задачу про знаходження найбільш ефективних груп науковців можна звести до задачі пошуку клік графру. Клікою в неорієнтованому граdpi називається підмножина вершин, кожні дві 3 яких з'єднані ребром графу. Іншими словами, це повний підграфр первісного графру. Розмір кліки визначається як число вершин в ній. [9]

Кліки графра у контексті задачі, що розглядається, е група вчених, кожен 3 яких проводив наукову діяльність 3 кожним іншим представником ціеї групи. У цій статті ставиться задача знаходження найбільшої кліки графру заданого підрозділу для визначення найедективнішої підгрупи науковців, у відповідності до класичної задачі теорії графрів - задачі про пошук максимальної кліки [10].

Основою для визначення максимальної кліки було використано наступний алгоритм. Після знаходження клік, дві кліки розміру $\mathrm{n}$ i m з'єднуються у велику кліку розміру $(\mathrm{n}+\mathrm{m})$, причому клікою розміру 1 покладаеться окрема вершина графру. Ітерація завершуеться, як тільки жодного злиття більше здійснити не можна. Після цього перевіряеться наступна пара клік.

Для демонстращіі методу використаємо дані по найбільшому підрозділу, що доступний для аналізу у якості первісного графу, а саме дані по всьому 3ВО. Максимальний розмір кліки, що була знайдена у первісному графрі, складає 6 . Дану кліку складають науковці ІФФ, кафедри фізики металів. Система аналізу надає змогу підрахувати спільне значення h-індексу будьякої заданої групи науковців. Спільний індекс Хірша науковців, що складають найбільшу кліку графру, рівний 11.

Знаходження кліків та наукометричних показників відповідних вчених дозволяе зрозуміти масштаб кооперації, а також визначити найбільш ефективні підгрупи вчених у рамках загальної групи.

Висновки. Результатом роботи є створена система, що дозволяе представити інформацію про взаемодію та найбільш продуктивні групи науковців на основі наукометричних даних, у емпіричній формі з метою спрощення прийняття управлінських рішень.

Робота показуе можливості прикладного аналізу з метою прийняття управлінських рішень, що може бути проведений за допомогою методів візуалізащії даних. Показники отримані з загальнодоступного джерела. Стаття описує методи, використані для побудови графоу наукової діяльності працівників закладу освіти НТУУ «КПІ ім. Ігоря Сікорського»; знаходження даних, що можуть відігравати ключову роль при вирішенні питання фінансування, прийняття управлінських рішень, та необхідності визначення впливу груп, або окремих індивідуумів на загальну картину наукометричних показників досліджуваної групи.

Можна зробити висновок про високий потенціал використання графової структури для роботи 3 наукометричними даними. Цей метод надає широкі можливості обробки даних, разом з тим залишаючи можливість їх простої візуалізації.

\section{Список літератури:}

1. Михайлов О. В. Об объективных критериях оценки качества научной деятельности. Науковедение. 2002. № 3. C. 179-185.

2. Маршалова И. В. Вітчизняні нотатки. 2002. № 7. С. 54-71.

3. Березінський Г. В. Аналіз наукометричних даних та складання рейтингу підрозділів КПІ ім. Ігоря Сікорського на основі публіцистичної діяльності викладачів : Матеріали IV всеукраїнської науково-практичної конференцї̈ молодих вчених та студентів "Інфорлаційні систели та технології управління" (ICTУ-2020). Київ : КПІ ім. Ігоря Сікорського, 24-30 квітня 2020. С. 110-117.

4. Мамонтов В. В., Березінський Г. В. Інформаційна система визначення критеріїв технології підтримки науково-публіцистичної діяльності науковців закладу вищої освіти : 001:004.91. Київ, 2020. С. 121.

5. Зятева О. А., Питухин Е. А. Управление научными показателями вуза: анализ публикационной активности. Перспективы науки и образования. 2019. № 4(40). С. 509-517.

6. Srinivasa G. Relevance of innovations in machine learning to scientometrics. Journal of Scientometric Research. 2019. № 8. P. 39-43.

7. Ulrik Brandes. A faster algorithm for betweenness centrality. Journal of Mathematical Sociology. 2001. Vol. 25. No. 2. P. 163-177.

8. Newman M.E.J. Networks: An Introduction. Oxford, UK : Oxford University Press, 2010.

9. Cook, Stephen A. The Complexity of Theorem-Proving Procedures. Proceedings of the Third Annual ACM Symposium on Theory of Computing. Shaker Heights, Ohio. 1971. P. 151-158.

10. Blair, Jean R.S., Peyton, Barry. "An introduction to chordal graphs and clique trees", Graph theory and sparse matrix computation. IMA Vol. Math. Appl., 56, Springer. New York, 1993. P. 1-2.

\section{References:}

1. Mihajlov O. V. (2002) Ob obektivnykh kriteriyakh ocenki kachestva nauchnoj deyatel'nosti. Naukovedenie, 3, 179-185.

2. Marshalova I. V. (2002) Vitchiznyani notatki, 7, 54-71.

3. Berezinskyi H. V. (2020) Analiz naukometrychnykh danykh ta skladannia reitynhu pidrozdiliv KPI im. Ihoria Sikorskoho na osnovi publitsystychnoi diialnosti vykladachiv. IV Vseukrainska naukovo-praktychna konferentsiia molodykh vchenykh ta studentiv "Informatsiini systemy ta tekhnolohii upravlinnia-ISTU-2020». Sektsiia kafedry avtomatyzovanykh system obrobky informatsii i upravlinnia. Materialy konferentsii. Kyiv.

4. Mamontov V. V., Berezinskyi H. V. (2020) Informacijna sistema viznachennya kriteriiv tekhnologii pidtrimki naukovo-publicistichnoi diyal'nosti naukovciv zakladu vishchoï osviti (kompleksna tema). Zagal'na chastina. 
Pidsistemi analizu naukometrichnikh ta publicistichnikh danikh naukovciv-vikladachiv. Individual'na chastina № 2. Bachelor's thesis, KPI im. Igorya Sikors'kogo.

5. Zyateva O. A., Pitukhin E. A. (2019) Upravlenie nauchnymi pokazatelyami vuza: analiz publikacionnoj aktivnosti. Perspektivy nauki i obrazovaniya, 4(40), 509-517.

6. Srinivasa G. (2019) Relevance of Innovations in Machine Learning to Scientometrics. Journal of Scientometric Research, 8(2s), pp. 39-43.

7. Brandes U. (2001) A faster algorithm for betweenness centrality. Journal of mathematical sociology, 25(2), $163-177$.

8. Newman M. E. J. (2010) Networks: An Introduction Oxford Univ.

9. Cook S. A. (1971, May) The complexity of theorem-proving procedures. In Proceedings of the third annual ACM symposium on Theory of computing (pp. 151-158).

10. Blair J. R., Peyton B. (1993) An introduction to chordal graphs and clique trees. In Graph theory and sparse matrix computation (pp. 1-29). Springer, New York, NY. 